\title{
Black Cohosh (Cimicifuga Racemosa) as Treatment of Menopause-Related Symptoms: A Mini Review Shoeb Qureshi
}

\author{
Shoeb Qureshi ${ }^{1 *}$, Hania Farhan ${ }^{2}$ and Viquar Fatima Qureshi ${ }^{3}$ \\ ${ }^{1}$ Department of Health Sciences, Research King Saud Bin Abdulaziz University for Health Sciences, Saudi Arabia \\ ${ }^{2}$ Department of Health Sciences, Manarat Al Riyadh International School, Saudi Arabia \\ ${ }^{3}$ Department of obstetrics and gynecology, King Abdul Aziz Medical City, Saudi Arabia
}

Submission: February 17, 2019; Published: March 21, 2019

*Corresponding author: Shoeb Qureshi, Department of Research, King Saud Bin Abdulaziz University for Health Sciences, National Guards, Saudi Arabia

Abstract

Black cohosh belongs to the family Cimicifuga racemosa. Root and rhizome are the medicinal parts of the herb. Black cohosh is used against the treatment of Menopause symptoms (including vasomotor); Premenstrual Syndrome (PMS); depression (mild); arthritis and migraine. It is often used as an alternative to estrogen-based replacement therapies to treat hot flushes that frequently accompany the transition to menopause.

Keywords: Black cohosh; Cimicifuga racemose; Menopause; Chemical constituents; Adverse effects

\section{Introduction}

Black cohosh belongs to the family Cimicifuga racemosa. Root and rhizome are the medicinal parts of the herb. Black cohosh is used against the treatment of Menopause symptoms (including vasomotor); premenstrual syndrome; depression (mild); arthritis and migraine [1-5]. It is often used as an alternative to estrogen-based replacement therapies to treat hot flushes that frequently accompany the transition to menopause [6,7]. However, definitive clinical data about efficacy have been equivocal [8]. Trials conducted by Pockaj et al. [8] found no evidence that black cohosh reduced hot flashes more than the placebo. As a constituent to Avlimil (a dietary supplement advertised to ameliorate female sexual dysfunction), black cohosh is suggested to have estrogenic, anti-estrogenic, or androgenic potential for relieving menopausal symptoms. Furthermore, DMSO extract of Avlimil was found to increase cell proliferation and cytotoxicity in MCF-7 (in vitro) at low and high concentrations, respectively Ju, et al. [9].

\section{Materials and Methods}

To accomplish the target on Black cohosh as treatment of menopause related systems and associated adverse effects, peer-reviewed English language articles published during 2 decades were selected from Pub Med, Pub Med Central, Science di rect, Up-to-date, Med Line, comprehensive data base, Cochrane library and the internet (Google, Yahoo).

\section{Chemical constituents}

The main constituents of Black cohosh are triterpenoids, phenolic compounds [9], phytoestrogens, isoflavones cimicifugoside, formononetin and salicylic acid [10].

\section{Toxicity}

Black cohosh significantly increased the incidence of lung metastases in tumor-bearing animals compared with mice fed the isoflavone-free control diet [6], and is reported to cause liver toxicity and induce micronuclei [11].

\section{Contraindications}

Contraindicated in individuals with a history of estrogen-dependent tumors or endometrial cancer. Black cohosh may cause nausea, vomiting, headache, and hypotension at higher dosages. Use with caution in individuals allergic to salicylates; it is not known whether the amount of salicylic acid is likely to affect platelet aggregation or have other effects associated with salicylates. Use with caution in individuals with hypotension or those taking antihypertensive medications.

Use with caution in individuals receiving anticoagulant medications. Monitoring of serum hormone levels is recommended after 6 months of use with black cohosh. Use with caution in in- 
dividuals with liver disease due to cases of liver damage [12-14]. Use with caution in patients with seizure disorder [15]. Contraindicated in pregnancy (based on in vitro or animal studies, may stimulate uterine contractions) and lactation [16].

To date, phytoestrogen-containing herbs have not been associated with the negative health effects seen with synthetic estrogen. However, use with caution in individuals on hormone replacement therapy or oral contraceptives, or a history of thromboembolic

\section{Theoretical interactions}

Oral contraceptives, hormonal replacement therapy, NSAIDs, anticoagulants, antihypertensives, drugs that lower the seizure threshold, hepatoxic drugs; cytochrome $\mathrm{P}_{450}, 3 \mathrm{~A} 4$, and 2D6 substrates.

\section{References}

1. Chung DJ, Kim HY, Park KH, Jeong KA, Lee SK et al. (2007) Black Cohosh and St. John's Wort (GYNO-Plus) for Flimacteric Symptoms. Yonsei Med J 48(2): 289-294.

2. McKenna DJ, Jones K, Humphrey S, Hughes K (2001) Black Cohosh: Efficacy, Safety, and Use in Clinical and Preclinical Applications. Altern Ther Health Med 7(3): 93-100

3. Oktem M, Eroglu D, Karahan HB, Taskintuna N, Kuscu E, et al. (2007) Black Cohosh and Fluoxetine in the Treatment of Postmenopausal Symptoms: A Prospective, Randomized Trial. Adv Ther 24(2): 448-461.

4. Wuttke W, Gorkow C, Seidlová-Wuttke D (2006) Effects of Black Cohosh (Cimicifuga Racemosa) on Bone Turnover, Vaginal Mucosa, and Various Blood Parameters in Postmenopausal Women: A DoubleBlind, Placebo-Controlled, and Conjugated Estrogens-Controlled Study. Menopause 13(2): 185-196.

5. Burke BE, Olson RD, and Cusack BJ (2002) Randomized, Controlled Trial of Phytoestrogen in the Prophylactic Treatment of Menstrual Migraine. Biomed Pharmacother 56(6): 283-288.

6. Davis VL, Jayo MJ, Ho A, Kotlarczyk MP, Hardy ML, et al. (2008) Black cohosh increases metastatic mammary cancer in transgenic mice expressing c-erbB2. Cancer Res 68(20): 8377-8383.

7. Leach MJ, Moore V (2012) Black cohosh (Cimicifuga spp.) for menopausal symptoms. Cochrane Database Syst Rev (9): CD007244. disease or stroke [17-21].

8. Pockaj BA, Gallagher JG, Loprinzi CL, Stella PJ, Barton DL, et al. (2006).

9. Ju YH, Doerge DR, Helferich WG (2008) A dietary supplement for female sexual dysfunction, Avlimil, stimulates the growth of estrogendependent breast tumors (MCF-7) implanted in ovariectomized athymic nude mice. Food Chem Toxicol 46(1): 310-320.

10. Kennelly EJ, Baggett S, Nuntanakorn P, Ososki AL, Mori SA, et al. (2002) Analysis of Thirteen Populations of Black Cohosh for Formononetin. Phytomedicine 9(5): 461-467.

11. Smith-Roe SL, Swartz CD, Shepard KG, Bryce SM, Dertinger SD, et al. (2018) Black cohosh extrfacts and powders induce micronuclei, a biomarker of genetic damage, in human cells. Enciron Mol Mutagen 59(5): 416-426.

12. Cohen SM, O'Connor AM, Hart J, Merel NH, Te HS (2004) Autoimmune Hepatitis Associated with the Use of Black Cohosh: A case Study. Menopause 11(5): 575-577.

13. Lontos S, Jones RM, Angus PW, Gow PJ (2003) Acute Liver Failure Associated with the Use of Herbal Preparations Containing Black Cohosh. Med J Aust 179(7): 390-391.

14. Lynch CR, Folkers ME, Hutson WR (2006) Fulminant Hepatic Failure Associated with the Use of Black Cohosh: A Case Report. Liver Transpl 12(6): 989-992.

15. Shuster J (1996) Heparin and Thrombocytopenia Black Cohosh Root? Chasteberry Tree? Seizures!. Hosp Pharm 1553-4.

16. Duker EM, Kopanski L, Jarry H, Wuttke W (1991) Effects of Extracts from Cimicifuga racemosa on Gonadotropin Release in Menopausal Women and Ovariectomized Rats. Planta Med 57(5): 420-424.

17. Walji R, Boon H,Guns E, Oneschuk D, Younus J (2007) Black cohosh (Cimicifuga racemosa [L.] Nutt.): safety and efficacy for cancer patients. Support Care Cancer. 15(8): 913-921.

18. Combest WL (1999) Black Cohosh. US Pharmacist 24(9): 46-55.

19. Ulbricht C, Basch E (2005) Natural Standard Research Collaboration. Natural Standard Herb and Supplement Reference - Evidence-Based Clinical Reviews, Elsevier, USA.

20. J Clin Oncol (2006) Phase III double-blind, randomized, placebocontrolled crossover trial of black cohosh in the management of hot flashes: NCCTG Trial N01CC1 24(18): 2836-2841.

21. Umland EM, Cauffield JS, Kirk JK, Thomason TE (2000) Phytoestrogens as Therapeutic Alternatives to Traditional Hormone Replacement in Postmenopausal Women. Pharmacotherapy 20(8): 981-990.

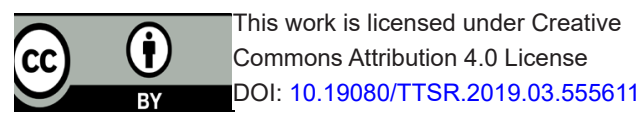

\section{Your next submission with Juniper Publishers will reach you the below assets}

- Quality Editorial service

- Swift Peer Review

- Reprints availability

- E-prints Service

- Manuscript Podcast for convenient understanding

- Global attainment for your research

- Manuscript accessibility in different formats

( Pdf, E-pub, Full Text, Audio)

- Unceasing customer service

\section{Track the below URL for one-step submission}

https://juniperpublishers.com/online-submission.php 